\title{
SPACE-FLIGHT AND RE-ENTRY TRAJECTORIES
}

\begin{abstract}
SYMPOSIUM on "Space-Flight and Re-entry Trajectories", organized by the International Academy of Astronautics, was held at Louveciennes, near Paris, during June 19-21, 1961. The conference was opened by Prof. Theodore von Kármán, who has chosen to follow up his long and distinguished career in aeronautics by becoming the first director of the Academy. This symposium constituted the first meeting of the Academy, and the subject of trajectories was ehosen, Prof. von Kármán said, because of its fundamental importance in the successful development of space flight. Though the Academy was now only beginning its activities, Prof. von Kármán was confident that in perhaps 100 years it would be as 'respectable' as the Academy of Sciences or the Royal Society. The present situation of astronautics reminded him of that of aeronautics when he first came to France in 1908. Then, aeronauts were regarded almost as madmen, and no one truly foresaw the later commercial and military applications of aircraft. Even the pioneer Lanchester was worried by the cost of upkeep of aerodromes, and thought they would have to be divided into two parts, to be grazed by cows in alternate years. With so many false aeronautical prophecies among his memories, Prof. von Kármán was confident of the future of astronautics.

The first scientific session, on "Trajectories for Lunar and Interplanetary Missions", began with a paper by J. M. J. Kooy (Breda, Netherlands) on "Astrodynamics and Planetary Research", which investigated the motion and uses of space-vehicles placed in orbit about a planet such as Venus. Then H. Hiller (Royal Aircraft Establishment, England) described the results of a generalized study of twodimensional trajectories in the region of the Earth and Moon, and W. E. Moeckel (U.S. National Aeronautics and Space Administration) discussed interplanetary trajectories for electrically propelled space vehicles.
\end{abstract}

The second session, on "Orbital Transfer and Rendezvous", comprised three papers on the optimization of interplanetary trajectories, by D. F. Lawden (Canterbury, New Zealand), P. Contensou (Office National d'Etudes et de Recherches Aéronautiques,
France) and B. Fraeijs de Veubeke (Liège, Belgium), and a general study of the techniques of orbital rendezvous by J. C. Houbolt (U.S. National Aeronautics and Space Administration). These subjects promise to expand greatly in the future, since both are essential to the economical performance of space missions and both pose severe mathematical problems.

In the third session, on "Near Earth Satellites", J. Kovalevsky (Bureau des Longitudes, Paris) made a general analytical review of orbital perturbations, D. G. King-Hele (Royal Aircraft Establishment, England) discussed the effect of atmospheric oblateness on satellite orbits, L. Sehnal (Ondrejov, Czechoslovakia) described luni-solar perturbations on a 24-hr, satellite, and K. Schütte (Munich) commented on the changes in the orbit of Echo 1.

The final session, on "Dynamics of Terminal Re-entry", was, ironically, delayed because the coach conveying the participants pursued a determinedly non-optimum terrestrial path from Paris to Louveciennes and took nearly $2 \mathrm{hr}$. to complete a journey nominally of 10 miles. In this session, A. Ferri and T. Ling (Brooklyn, U.S.A.) described the effect of varying lift on re-entry trajectories, W. F. Hilton (Hawker Siddeley, England) considered re-entry paths which avoid the zones of radiation, and errors in re-entry guidance were discussed by T. R. F. Nonweiler (Queen's University, Belfast) and L. Broglio (Rome). Finally, J. V. Becker, D. L. Baradell and E. B. Pritchard (U.S. National Aeronautics and Space Administration) investigated the methods of control for re-entry from escape speeds.

Although some of the papers seemed to be slightly out of touch with the present realities of space research, this was perhaps appropriate, or even inevitable, in a forward-looking academic symposium. Certainly the symposium as a whole can be counted a success, and the International Academy of Astronautics was wise to limit the numbers of those attending to about 80 . Representatives from the U.S.S.R. were invited, but were unable to come. The papers presented at the symposium are to be published in Astronautica Acta later this year.

D. G. KING-HeLE

\section{BIOLOGY IN BRITAIN}

\section{By DR. H. V. WYATT}

\section{Department of Bacteriology, University of Leeds}

CINCE the War, more and more exciting discoveries $\checkmark$ have been made in biology, but the classical biology of pre-war years has changed little. New techniques and brilliant men have opened new and fundamental subjects of inquiry, which cannot be wholly contained by the separated disciplines of botany and zoology but have found equal application in both subjects. Perhaps for the first time there is now a subject that can be called 'biology'.

A British biologist visiting the United States has at least two shocks in store for him; the first is the breadth of interest of his American colleagues and the second is the scope of the American undergraduate programme. In the United States there are departments in biology where the staff may include an ecologist, a physiologist, a biochemist, a microbial geneticist, a plant pathologist and perhaps an embryologist. An undergraduate may study zoology, botany, biochemistry, microbiology and genetics as well as chemistry. Afterwards, if he undertakes postgraduate studies, he will attend courses in an even greater variety of subjects. We may be doubtful and scoff 'superficial' 
and 'multiple-choice', and there are certainly faults in the American educational system, but the American biology graduate and Ph.D. is better equipped than the British counterpart, better equipped to teach other subjects, better equipped to read the journals, better equipped to do and to direct research. The advances that are being made are the results of the application of the techniques of one subject in others. Embryology is now studied by using techniques of biochemistry and immunology ; major advances have been made in genetics by the use of micro-organisms; micro-organisms have contributed to our understanding of biochemistry and now the biochemistry of deoxyribonucleic acid, the chemical basis of heredity, is being studied by using the viruses that infect bacteria. The artificial barriers are down: only the complete biologist can hope to map the new territories, although all the time the discovery of new landmarks makes it easier to find the way.

The emphasis in teaching is on the vertical division: animals and plants are catalogued in an ascending scale of morphological complexity corresponding to the natural evolution of the groups. But British practice in research is based increasingly on a horizontal structure; people who work on the active transport of inorganic ions and organic molecules use yeast, bacteria, plant roots, parasitic worms, mammalian red blood cells and so on. The fundamental properties of active transport are probably the same in all cells and can be studied in any convenient system; methods of studying it are peculiar to active transport and do not depend on the type of cell. From these studies we may discover whether cells of different origin behave in the same way or whether those differences we find have an evolutionary or an ecological significance. Already we have a pragmatic subject, microbiology, in which unity derives from common techniques and not from an evolutionary concept of a common ancestor. Research emphasizes the unity of modern biology; our teaching must do the same, for only by teaching biology as a unified discipline can we hope to train biologists adequately. It is essential that while we teach the latest findings of biochemistry and biophysics, we also give our students a love and understanding of living plants and animals. If the biologist is taught little biochemistry, the biochemist lacks contact with the living.

Many subjects are taught in isolation when their integration would make plain their coherent pattern. Recent experiments have shown that diet and behaviour may influence the interaction of parasite and host; behaviour is affected by the hormone balance of the animal, and this in turn is influenced by the animal's environment. We must frame our courses so that the student is made aware of such complex interactions. To do this we must persuade the staffs of our universities from the isolation of their departments. A degree of trade union demarcation. has begun in our subjects; we now specialize so early that there is a tendency for the student with a first degree in microbiology, for example, to be restricted. to that subject; although his techniques could be used there to advantage, he is rarely encouraged to apply for a job in a zoology department.

If the new biology is experimental and not in the first place descriptive, on what shall we model our course? At least one course that we could copy is already in existence. For the Diploma of Technology in applied biology at the colleges of technology the emphasis after the first year is on physiology, biochemistry, pharmacology and microbiology. Element- ary mathematics, statistics and organic and physical chemistry are also compulsory subjects. It is significant that these courses were planned by departments of biology in colleges where there had been no fragmentation into minor subjects. Although these courses have been planned with the view of the needs of industry, they are more suited for academic biology and research than are the courses offered at the universities. Sixth-form students may well think so too, as they read the topics and experience required in the "Situations Vacant" columns. Already our students may be learning more about modern biology from the New Scientist, the Penguin Science Survey and television than they gain from the isolated subjects studied at a university.

It is important that, in presenting the mosaic to show both the pattern and the basic units, we do not leave the student either bewildered or complacent. Bewildered if, faced with two thousand references about a single animal, he cannot imagine what more can be discovered or where to start; complacent, if he is presented with knowledge as a set of facts and theories and techniques as unquestionable. Both might be avoided by a detailed observation that would give competence with several techniques, an appreciation of the complexity of an organism and, most of all, an awareness that science is not dormant but militant. One evident way to attempt this would be to give a class several strains of a bacterium. Each week the class would study their own cultured strains in a progressive series of experiments. These could include growth, nutritional requirements, antibiotic sensitivity, genetics and phage-susceptibility - each of which contributes to the understanding of the others. If we base our undergraduate courses on modern experimental techniques with wide application, we can shed some of the crafts which now occupy so much time in school and university. As we do so, we may attract students who now take the physical sciences.

As soon as possible we must bring all the biological sciences together in one building. This is necessary not only so that the staff may feel that they are all biologists but in order that courses can be integrated. Staff using the same or similar techniques will be encouraged to collaborate and form new loyalties. Apparatus can be shared for both teaching and research. Physical and financial separation now makes this difficult. With the present departmental system, expensive apparatus is bought by one department, used, and afterwards lies idle. In another department, similar equipment is bought from another source. While we lack in the universities much modern equipment necessary for research, we continue to buy two pieces of apparatus where one would suffice.

A director of the National Science Foundation, which is revolutionizing the teaching of science in the United States, has written of the need for more experimental biology in Europe ${ }^{1}$. In Britain recently there has been argument for the creation of more chairs of biochemistry and molecular biology or biophysics. The need for such chairs is urgent: Prof. Irene Manton, in a recent broadcast, suggested that more chairs be created within existing departments; and, I may add, we need fusion of the biological sciences for teaching and research. Within a unified department of biology, it will be easier to add new disciplines than it is, nowadays, to create new departments.

${ }^{1}$ Consolazio, W. V., Science, 133, 1892 (1961). 